\title{
Persepsi Masyarakat terhadap Kegiatan Mangkal Waria di Kelurahan Sipolu-Polu Kecamatan Panyabungan Kabupaten Mandailing Natal
}

\author{
Nurhamidah \& Waston Malau* \\ Program Studi Pendidikan Antropologi \\ Fakultas Ilmu Sosial, Universitas Negeri Medan, Indonesia
}

Diterima: Desember 2018; Disetujui: Desember 2018; Dipublish: Desember 2018

E-mail: wastonmalau@unimed.ac.id

\begin{abstract}
Abstrak
Penelitian ini bertujuan untuk mengetahui latar belakang seseorang menjadi waria, kegiatan para waria, persepsi masyarakat waria terhadap masyarakat dan persepsi masyarakat terhadap kegiatan mangkal waria di Kelurahan Sipolu-Polu Kecamatan Panyabungan Kabupaten Mandailing Natal. Penelitian ini menggunakan jenis penelitian kualitatif yang bersifat deskriptif. Teknik pengumpulan data melalui observasi, dokumentasi dan wawancara. Penelitian ini dilakukan di Kelurahan Sipolu-Polu Kecamatan Panyabungan Kota Kabupaten Mandailing Natal mengenai persepsi masyarakat terhadap kegiatan mangkal waria. Penentuan informan dalam penelitian ini dilakukan menggunakan teknik purposive sampling. Adapun informan dalam penelitian ini adalah empat orang waria, tokoh agama, tokoh adat, dan tokoh masyarakat dan masyarakat sekitar. Hasil penelitian ini menunjukkan bahwa, hal yang menjadi latar belakang seseorang menjadi waria adalah: Faktor Keluarga, Faktor Traumatis, Faktor Lingkungan Sepermainan, dan Faktor Peran. Tetapi, masyarakat sekitar tidak menerima keberadaan mereka, khususnya kegiatan mangkal mereka, masyarakat sangat menentang keras itu.

Kata Kunci: Waria, Persepsi Masyarakat.
\end{abstract}

\begin{abstract}
This study aims to determine a person's background became transgender, transvestites activities, public perception of the transgender community and the public perception of hung shemale activities in Sub-Polu Sipolu Panyabungan District of Mandailing Natal. This research uses descriptive qualitative research. The technique of collecting data through observation, documentation and interview. The research was carried out in Sub-Polu Sipolu Panyabungan City District of Mandailing Natal regarding the public perception of hung shemale activity. Determination of informants in this study using purposive sampling technique. The informants in this study were four transgender people, religious leaders, traditional leaders, and community leaders and the community around. The results of this study show that, it is the background of a person to be transvestites are: Factor Family, Traumatic Factors, Environmental Factors sepermainan, and Factor Role. However, the community did not accept their existence, especially hung their activities, people are very opposed to it.
\end{abstract}

Keywords: Shemale, Public Perception.

How to Cite: Nurmaidah \& Malau. W (2018). Persepsi Masyarakat terhadap Kegiatan Mangkal Waria di Kelurahan Sipolu-Polu Kecamatan Panyabungan Kabupaten Mandailing Natal. Journal of Education, Humaniora and Social Sciences (JEHSS). 1 (2): 104-109.

\section{PENDAHULUAN}

Masyarakat adalah sebuah kumpulan individu yang memiliki sebuah norma dan nilai sosial didalamnya yang tujuannya untuk menata keteraturan dalam masyarakat itu. Norma dan nilai diperoleh bukannya tanpa proses, melainkan lewat proses berbagai macam kepentingan dan perbedaan antar individu dengan pedoman agama atau kepercayaan yang berlaku dalam masyarakat tersebut. Ketika nilai-nilai dan norma-norma dalam masyarakat yang telah disepakati bersama telah dilanggar, maka akan terjadi suatu kondisi yang tidak teratur dalam masyarakat tersebut dan hal ini akan menyebabkan adanya disintegrasi dalam masyarakat.

Setiap manusia dalam hidupnya akan selalu berkembang dan harus melalui tahap-tahap perkembangannya. Akibat dari perkembangan tersebut, manusia akan mengalami perubahanperubahan, baik fisik maupun psikologisnya. Perkembangan manusia tidak akan dapat 
dilepaskan dari interaksi antara unsur biologis, psikologis, dan social. Ketiga unsur ini saling mempengaruhi sebagai satu kesatuan (Maramis, dalam Kurniawati (2003). Dalam kurun waktu perkembangan tersebut, tidak setiap individu akan berkembang sesuai dengan perkembangan fisiknya. Sebagai contoh, tidak semua anak laki-laki akan berkembang menjadi laki-laki sesungguhnya, dan tidak semua anak perempuan akan berkembang menjadi perempuan sesungguhnya. Bisa saja terjadi, anak laki-laki akan berkembang menjadi waria dan anak perempuan berkembangan menjadi tomboy.

Misalnya kemunculan waria, kita semua mengenal waria (wanita tapi pria), waria adalah individu yang memiliki jenis kelamin laki-laki tetapi berperilaku dan berpakaian seperti layaknya seorang perempuan. Waria merupakan kelompok minoritas dalam masyarakat, namun demikian jumlah waria semakin hari semakin bertambah, terutama di kota-kota besar di Indonesia. Seiring dengan perubahan zaman, keberadaan waria pun tidak hanya di kota-kota besar, melainkan di kota-kota kecil pun sudah ada waria, bahkan di pedesaan pun sudah ada waria. Kaum waria merupakan suatu paparan nyata yang tidak dapat ditolak eksistensinya di masyarakat. Belum banyak orang yang mengetahui seluk-beluk kehidupan waria yang sesungguhnya. Keberadaan waria seakan penuh dengan nilai-nilai negatif dalam pribadi seseorang dan segala sesuatu yang berhubungan dengan kehidupannya, karena didalam kehidupan masyarakat sering mendengar bahkan sering melihat bagaimana sebenarnya kehidupan waria dipenuhi dengan kekerasan fisik maupun psikis, waria juga sering mengalami pelecehan-pelecehan seksual dan juga penolakanpenolakan yang dilakukan oleh tokoh masyarakat dan tokoh agama, serta pandangan-pandangan negatif yang tidak berujung dan tidak beralasan dari masyarakat pada umumnya yang menyebabkan kehidupan waria terganggu secara psikis.

Waria juga manusia yang memiliki perasaan dan bisa merasakan sakit hati akibat perlakuan-perlakuan yang tidak wajar yang sering mereka terima, karena mereka juga mempunyai harga diri yang seharusnya dilindungi bukan dihina seperti saat ini yang mereka alami, mereka hanya ingn menerima pengakuan dari masyarakat saja tentang keberadaan mereka. Perilaku waria juga tidak dapat dijelaskan dengan deskripsi yang sederhana. Dalam artikelnya tentang waria, Suharyanto (2015), juga mengungkapkan bahwa sebetulnya mereka sedang mengalamipergulatan sosial dan konflik identitas di tengah masyarakat. Karena konflik identitas jenis kelamin yang dialami waria tersebut hanya dapat dipahami melalui kajian terhadap setiap tahap perkembangan dalam hidupnya. Setiap individu akan selalu berkembang, dari perkembangan tersebut individu akan mengalami perubahan-perubahan baik fisik maupun psikologis. Salah satu aspek dalam diri manusia yang sangat penting adalah jenis kelamin. Berperilaku menjadi waria memiliki banyak resiko. Waria dihadapkan pada berbagai masalah seperti penolakan keluarga, kurang diterima atau bahkan tidak diterima secara sosial, dianggap lelucon, hingga kekerasan baik verbal maupun non verbal

Dari latar belakang masalah diatas, maka peneliti tertarik untuk meneliti lebih lanjut dengan tujuan agar mendapatkan pemahaman yang lebih mengenai "Persepsi Masyarakat Terhadap Kegiatan Mangkal Waria Di Kelurahan Sipolu-Polu Kecamatan Panyabungan Kabupaten Mandailing Natal “.

\section{METODE PENELITIAN}

Jenis penelitian yang digunakan dalam penelitian ini adalah penelitian lapangan dengan metode penelitian kualitatif yang bersifat deskriptif mengenai "Persepsi Masyarakat Terhadap Kegiatan Mangkal Waria di Kelurahan Sipolu-Polu Kecamatan Panyabungan Kabupaten Mandailing Natal". Menurut Bogdan dan Tylor dalam (Moleong, 2006) bahwa metode kualitatif sebagai prosedur penelitian menghasilkan data deskriptif berupa kata-kata tertulis atau lisan dari orang-orang atau pelaku yang kita amati.

Penelitian ini dilakukan di salah satu cafe yang berada di Kelurahan Sipolu-Polu Pemilihan lokasi ini karena di Kelurahan tersebut para waria melakukan aktifitas di siang hari seperti salon, dan kegiatan malam waria juga berada di Kelurahan tersebut seperti mangkal dan cafenya juga 
berada di Kelurahan Sipolu-Polu. Pemilihan lokasi ini dilakukan untuk memperoleh data yang diinginkan yang berkaitan dengan permasalahan dalam penelitian.

Yang menjadi Subjek penelitian ini adalah para waria yang berada di Kota Panyabungan Kecamatan Panyabungan Kota yang berprofesi sebagai waria sebagai subjek penelitian. Dalam penelitian ini, peneliti memilih 4 orang waria sebagai subjek penelelitiannya. Masyarakat sekitar yaitu, tokoh masyarakat, pemuka agama, tokoh adat, masyarakat biasa yang bertempat tinggal di Kelurahan Sipolu-Polu, remaja yang bertempat tinggal di kelurahan Sipolu-Polu dan remaja tersebut memanfaatkan keberadaan waria yang ada di kelurahan Sipolu-Polu, sebagai tempat mangkalnya para waria pada malam hari. Peneliti menggunakan teknik purposive sampling yaitu sampel diambil dengan maksud dan tujuan tertentu sesuai dengan tujuan penelitian. Sedangkan yang menjadi Objek peneliti adalah kelurahan Sipolu-Polu kecamatan Panyabungan Kabupaten Mandailing Natal. Tepatnya di salah satu cafe yang berada di Kelurahan Sipolu-Polu. Penelitian dilaksanakan kurang lebih selama dua bulan.

\section{HASIL DAN PEMBAHASAN}

Fenomena waria merupakan salah satu bagian dari masyarakat yang mengalami suatu proses yang ditandai dengan adanya pertentangan, yang kehadirannya belum seutuhnya diterima oleh masyarakat. Keberadaan waria dianggap sebagai perilaku menyimpang. Soerjono Soekanto berpendapat bahwa perilaku menyimpang adalah penyimpangan terhadap kaidah dan nilai masyarakat. Menurutnya, faktor penyebab terjadinya perilaku menyimpang diantaranya faktor keadaan ekonomi dan sosialisasi yang kurang sempurna.

Hal ini terjadi karena ketidaksepadanan pesan-pesan yang disampaikan oleh masingmasing agen sosialisasi, pengambilan peran yang salah atau karena belajar pada sub kebudayaan yang menyimpang. Salah satunya terjadi di lingkungan keluarga (Soekanto, 1988). Merujuk pada pendapat Soekanto tersebut diatas, dapat dilihat beberapa faktor yang melatar belakangi seseorang menjadi waria, diantaranya sebagai berikut: Faktor Ekstern Faktor ini berasal dari luar diri seseorang yang merasa dirinya mempunyai jiwa keperempuanan. Faktor tersebut seperti penampilan fisik seorang lelaki yang menyerupai wanita, cara berbicara dan berparas menawan serta lain sebagainya. Kemudian faktor ekstern dibagi menjadi 5 faktor, 1) Faktor Lingkungan Keluarga; 2) Traumatis; 3) Faktor Lingkungan Masyarakat; 4) Faktor Labelling; 5)

Faktor lingkungan keluarga, memang tidak dapat dipungkiri, lingkungan keluarga merupakan faktor pendukung terbesar yang menentukan pembentukan perilaku dan kepribadian seseorang. Termasuk menentukan waria atau tidaknya seorang pria. Berikut petikan wawancara peneliti dengan Muhammad Iqbal (Rihanna) salah satu waria yang sedangbekerja di salon perihal faktor lingkungan keluarga yang melatarbelakangi pembetukan kepribadiannya. pada tanggal 15 April 2016 sebagai berikut :

“...Saya sebenarnya dek berasal dari keluarga yang tidak mampu, kemudian orang tua saya meninggal, sementara adik saya masih sekolah, abang dan kakak saya sudah berkeluarga, saya merasa tidak mungkin lagi mengganggu kehidupan abang dan kakak saya untuk membiayai adik saya, sehingga saya memutuskan untuk mencari nafkah untuk membiayai hidup saya dan menyekolahkan adik saya, sebenarnya saya pernah bekerja menjadi kuli bangunan, tetapi saya tidak tahan kerja keras, kemudian pada waktu itu saya senang berkumpul dengan teman saya yang kebetulan punya salon dek, dan saya diajak untuk ikut gabung dengan mereka, kemudian saya tertarik dan sekarang saya senang dengan pekerjaan yang saya jalanin ini...")

Faktor traumatis memang bisa menjadi pemicu seorang laki-laki memutuskan untuk menjadi waria. Boleh jadi karena ia sempat disakiti perempuan sehingga memutuskan untuk menyukai sesama jenis dengan jalan mengubah tampilan menjadi waria. Faktor ini terjadi di masa lalu sesorang yang tidak bisa dilupakanya, sehingga ia merasa nyaman saat menjadi waria, sebagai cara yang bisa membuatnya lupa (pelampiasan), penyebab trauma ini biasanya berupa perlakuan tidak senonoh seperti tindak asusila, disakiti, dihianati oleh lawan jenisnya pada tanggal 15 April 2016 sebagai berikut:

"...semasa SMA saya pernah menjalin hubungan dengan wanita, kemudian di khianati dengan pacar saya, dia menikah dengan orang lain, semenjak saat itu saya belum bisa melupakan 
wanita itu, kemudian saya memutuskan untuk mencari pasangan kembali tetapi ingin mecoba menjalin dengan sesama jenis, dikarenakan pacaran dengan lawan jenis sudah biasa dan membuat sakit hati dan trauma, dan ditambah dengan rasa penasaran bagaimana rasanya pacaran dengan sesama jenis, tidak lama kemudian saya pun berhasil mendapatkan apa yang saya inginkan, saya menjalin hubungan dengan seorang bencong, selama dua bulan hubungan kami baik-baik saja. sejak itulah orang tua saya mengetahui tentang sikap saya dan disuruh meninggalkan rumah dan tidak dibiayai kehidupan saya lagi dengan orang tua, kemudian saya tinggal dengan pacar saya, namun hal itu tidak berlangsung lama, kemudian kami putus dan saya pun mencari pekerjaan dengan untuk membiayai kehidupan saya, tidak berapa lama saya mendapatkan pekerjaan sebagai karyawan salon dan tinggal disana, tidak lama saya bekerja disana saya mengalami perubahan yang drastis, seperti gaya bicara, pakaian, gerak gerik mengikuti keadaan di dalam salon yaitu laki-laki seperti wanita. Dan sampai sekarang saya masih menjalin hubungan dengan seorang laki-laki, dan saya belum mempunyai niat untuk kembali ke dalam kehidupan ku yang sebenarnya, yaitu untuk menjadi laki-laki yang sebenarnya.)

Faktor lingkungan masyarakat di sekitar tempat tinggal seseorang mempunyai peran yang cukup signifikan dalam pembentukan karakter sesorang. Seorang laki laki yang dari kecil tinggal dikawasan lokalisasi atau salon waria, atau berteman dengan perempuan dan bermain mainan perempuan menjadikan dirinya cenderung menumbuhkan sikap feminim, inilah benih-benih waria dalam diri lelaki. Berikut petikan wawancara dengn Ibrahim (santi) salah satu waria yang bekerja di salon perihal faktor lingkungan yang melatarbelakangi pembentukan kepribadiannya.

“...Semasa kecil, nenek saya lebih sering membelikan mainan perempuan dari pada mainan laki-laki, dan dalam keseharianpun saya sering bergaul dengan perempuan, ketika tamat SD orang tua saya memberi inisiatif untuk menyekolahkan saya ke pesantren agar kebiasaan saya berteman dengan perempuan berkurang, sebab dipesantren sudah diatur formasi untuk laki-laki dan perempuan, laki-laki dan perempuan dipisahkan sehingga besar kemungkinan saya dapat berubah, dengan seiring waktu saya mengalami perubahan hingga kelas dua semester satu, selama itu saya tidak bergaul dengan perempuan dan ketika pulang kampung saya hanya mengurung diri di dalam rumah. Seteleh itu pada kelas dua semester dua saya mendapatkan teman baru yang mempunyai sifat keperempuanan di pesantren tersebut, dia mengajak untuk ikut bergabung ke group mereka dan saya mulai tertarikdan menawarkan bekerja sebagai karyawan salon tetapi saya menolaknya karena saya masih menghargai pesantren saya dan alhasil saya hanya bergabung dengan perkumpulan mereka tetapi tidak dengan pekerjaan mereka, hingga saat di kelas tiga saya mulai merasa tertarik dengan pekerjaan saya, alhasil saya pun keluar dari pesantren dan melanjutkan ke SMA Negeri, semenjak kelas satu SMA hingga akhir saya sudah mulai ikut bekerja di salon tersebut dan kesekolah pun saya memakai makeup, dan bahkan guru saya pun tidak berani lagi menegur saya karena keras kepala tidak mendengarkan apa nasihat yang diberikan oleh guru).

Faktor Labelling yang jika dikaji dari makna labeling itu sendiri adalah penyimpangan yang disebabkan oleh pemberian cap/ label dari masyarakat kepada seseorang yang kemudian cenderung akan melanjutkan penyimpangan tersebut. misalnya pencuri, penipu, pemerkosa, pemabuk, dan sebagainya. Sebagai tanggapan terhadap cap itu, si pelaku penyimpangan kemudian mengidentifikasikan dirinya sebagai penyimpang dan mengulangi lagi penyimpangannya sehingga terjadi dengan penyimpangan sekunder (secondary deviation). Seperti yang dialami oleh Ibrahim alias Santi pada awalnya sedikit gemulai dan terkesan mentel di cap atau diberi label banci. Awalnya hanya perilaku menyimpang pada tahap primer (pertama) lalu oleh masyarakat diberi cap banci, maka Ibrahim alias Santi terdorong untuk melakukan penyimpangan sekunder (tahap lanjut) menjadi seorang waria.

Faktor peran yang menggambarkan interaksi sosial dalam terminologi aktor-aktor yang bermain sesuai dengan apa-apa yang ditetapkan oleh budaya. Sesuai dengan teori ini, harapanharapan peran merupakan pemahaman bersama yang menuntun kita untuk berperilaku dalam kehidupan sehari-hari. Menurut teori ini masyarakat yang dibarengi dengan yang namanya pemahaman tentang peran-peran secara otomatis akan lebih paham dalam berinteraksi dengan 
lingkungan sekitarnya, karena segala sesuatu yang diajarkan dengan peran adalah salah satu fakor utama dalam mencapai kepuasan tersendiri bagi individu untuk menjalankan sebuah fungsi. Berikut petikan wawancara peneliti dengan Maulana (Dora) salah satu waria yang bekerja di salon perihal faktor peran yang melatarbelakangi pembentukan kepribadiannya.

Kehidupan waria yang beragam latar belakang penyebab, menjalani proses kehidupan yang hampir sama. Proses-proses itulah yang mereka lalui. Demikian kelompok waria (tidak sengaja dibentuk) di tengah kehidupan masyarakat. Berpenampilan yang menunjukkkan simbol-simbol keberadaan mereka, seperti pakaian yang mereka pakai, aksesoris yang mereka gunakan ataupun bahasa khusus mereka dan aktivitas mereka yang mencerminkan perilaku mereka. Dimana semuanya itu mendapat penilaian dari respon aktor lain, yaitu masyarakat.

“...Saya kak dari mulai umur 10 tahun sudah memiliki kecenderungan menyukai hal-hal yang feminim, tetapi tidak berani memakai pakaian yang persis pakaian perempuan, tingkah laku, gaya berjalan dan gaya berbicara cenderung seperti perempuan, semua pekerjaan rumah juga saya yang menanggungjawabinya, saya memiliki hobi menari dan dandan, karena hoby saya menari saya sering di panggil guru TK dan SD setempat untuk melatih murid-muridnya sekaligus untuk merias dan pada acara wisuda TK saya juga sering di panggil untuk merias anak-anak TK, karena saya sering melatih dan merias anak TK, maka orang-orang yang berada di sekitar saya sering memanggil panggilan nama saya dengan "Dora banci" atau "Dora bencong" pada awalnya keluarga saya tidak setuju dengan kegiatan saya tetapi setelah saya membuktikan dengan bakat yang saya miliki sempat menghasilkan uang, saya dapat membuka salon sendiri dan membiayai hidup saya, setelah buka salon, penampilan saya semua berubah ditambah saya memang lebih menyukai pakaian yang feminim, sehingga saya merasa nyaman, ketika itu saya tidak berani pulang kerumah karena takut di marahi orang tua, tetapi lama-kelamaan saya berani dan orang tua saya tidak mau mengambil tindakan apa-apa dikarenakan saya sendiri yang membiayai kehidupan saya bahkan kadang-kadang saya lagi yang memberi uang kepada orang tua saya).

Kehidupan waria yang beragam latar belakang penyebab, menjalani proses kehidupan yang hampir sama. Proses-proses itulah yang mereka lalui. Demikian kelompok waria (tidak sengaja dibentuk) di tengah kehidupan masyarakat. Berpenampilan yang menunjukkkan simbol-simbol keberadaan mereka, seperti pakaian yang mereka pakai, aksesoris yang mereka gunakan ataupun bahasa khusus mereka dan aktivitas mereka yang mencerminkan perilaku mereka. Dimana semuanya itu mendapat penilaian dari respon aktor lain, yaitu masyarakat.

\section{SIMPULAN}

Masyarakat menolak keras keberadaan mangkal waria dan sangat tidak bisa menerima waria di sekitar tempat tinggal mereka, terutama dengan kegiatan mangkal mereka karena masyarakat merasa sangat diresahkan dan mengganggu kenyamanan dan merasa waria menjadi perusak citra masyarakat. Dan menjatuhkan martabat masyarakat Mandailing Natal. Dalam berperilaku di masyarakat, waria berperilaku baik dengan masyarakat, dilihat dari kegiatan waria, mereka tidak saling mengganggu, dan dalam keseharian mereka juga tidak meresahkan warga, dan para waria juga ikut berpartisipasi dalam kegiatan-kegiatan tertentu yang diadakan oleh masyarakat.

Mangkal diartikan sebagai suatu tempat perkumpulan beberapa orang yang masuk kedalam suatu organisasi dan melakukan kegiatan-kegiatan tertentu. Tempat mangkal ini juga merupakan tempat pemberhentian atau jual beli (tawar menawar). Khususnya pada tempat mangkal waria ini, di tempat inilah para waria berkumpul dan bahkan bagi mereka tempat mangkal ini adalah rumah kedua mereka.Masyarakat adalah pergaulan hidup manusia (sehimpunan orang yang hidup bersama dalam sesuatu tempat dengan ikatan-ikatan yang tertentu). Masyarakat adalah sekelompok orang yang mempunyai identitas sendiri, yang membedakan dengan kelompok lain dan hidup dan diam dalam wilayah atau daerah tertentu secara tersendiri. Kelompok ini baik sempit maupun luas mempunyai perasaan akan adanya persatuan di antara anggota kelompok dan menganggap dirinya berbeda dengan kelompok lain 


\section{DAFTAR PUSTAKA}

Atmojo, K. (1987). Kami Bukan Lelaki: Sebuah Sketsa Kehidupan Kaum Waria. Jakarta: LP3ES

Barnhouse, R.T. (1988). Identitas Wanita. Yogyakarta: KANISIUS.

Black, J.A. Champion, D.J. (2009). Metode dan Masalah Penelitian Sosial. Bandung: PT. Refika Aditama.

Departemen Pendidikan dan Kebudayaan, (1990). Kamus Besar Bahasa Indonesia. Jakarta: Balai Pustaka Faisal, S. (1999). Format-format Penelitian Sosial. Jakarta: PT. Raja Grafindo Persada.

Horton, F.B. Hunt LC. (1999). Sosiologi dan Masyarakat. Jakarta: PT. Gelora Aksara Pratama.

Koentjaraningrat. (1997). Metode-Metode Penelitian Masyarakat. Jakarta: PT Gramedia Pustaka Utama

Koeswinarno. (2004). Hidup Sebagai Waria. Yogyakarta: Pelangi Karya

Moleong, J.L. (2010). Metode Penelitian Kualitatif. Bandung: Rosdakarya Oofsset.

Nadia, Z. (2005), Waria Laknat atau Kodraat. Yogyakarta: Pustaka Marwa

Ritzer, G. (1985). Sosiologi Ilmu Pengetahuan Berparadigma Ganda. Jakarta: Rajawali Press.

Sears, O.D. (1985). Psikologi Sosial. Jakarta: Airlangga

Soekanto, S, (2001). Sosiologi Suatu Pengantar. Jakarta: Raja Grafindo Persada

Sugiyono, (2012). Metode Penelitian Kuantitatif Kualitatif dan R \& D. Bandung: Alfabeta.

Suharyanto, A. (2015). Waria dalam Pandangan Antropologi Tubuh, Anthropos: Jurnal Antropologi Sosial dan Budaya, 1 (1): 94-101.

Suyono, A. (1985). Kamus Antropologi. Jakarta: Akademi Pressindo. 